\title{
Editorial: Law in Context for the Digital Age
}

By Pompeu Casanovas, La Trobe University, Melbourne, Australia, Orcid: http://orcid.org/0000-0002-0980-2371

Jianfu Chen, La Trobe University, Melbourne, Australia, Orcid: http://orcid.org/0000-0002-4711-6524

David Wishart, La Trobe University, Melbourne, Australia, Orcid: http://orcid.org/0000-0003-2281-4745

\begin{abstract}
We introduce both the new inception of Law in Context - A Socio-legal Journal and the continuing issue of LiC 36 (1). The editorial provides a brief historical account of the Journal since its inception in the early 1980s, in the context of the evolution of the Law \& Society movement. It also describes the changes produced in the digital age by the emergence of the Web of Data, Big Data, and the Internet of Things. The convergence between Law \& Society and Artificial Intelligence \& Law is also discussed. Finally, we introduce briefly the articles included in this issue.
\end{abstract}

Keywords - Law in Context, Law and Society, Socio-legal research, Artificial Intelligence, Digital Society

Acknowledgments. This edition and the launch of LiC is partially funded by a La Trobe University Research Infrastructure Plan grant.

Disclosure statement - No potential conflict of interest was reported by the author.

License - This work is under Attribution-NonCommercial-ShareAlike 4.0 International (CC BY-NC-SA 4.0) https://creativecommons.org/licenses/by-nc-sa/4.0/

Suggested citation: P. Casanovas, J. Chen and D. Wishart (2019). "Editorial: Law in Context for a Digital Age." Law in Context, 36 (1): 3-11. DOI: http://doi.

org/10.26826/law-in-context.v36i1.91.

\section{Summary}

1. Law in Context (LiC) in context

2. Context and Law in the Digital Age

3. About this Edition: Law in Context for the Digital Age

4. Law in Context in Open Access

\section{LAW IN CONTEXT (LIC) IN CONTEXT}

Volume 36 (1) of Law in Context constitutes a renewed Law in Context - A Socio-legal Journal. From 2019 onwards it will be published in Open Access at no cost to either the authors or the readers. It thus represents a new stage in the Journal's long and fruitful history.

The Journal was launched in 1983 at the then Department of Legal Studies of La Trobe University by Oliver
Mendelsohn (as General Editor), Martin Chanock (as Book Editor) and Ian Patterson (as Business Manager). Although Law in Context ( $\mathrm{LiC}$ ) was launched after the retirement in 1982 of E.K. Braybrooke, the charismatic founder of the Department, it retained his realistic stamp. It is worth noting that many members of the so-called "First Legal Scholarly Community" in Australia, after World War II, 
were closer to American legal realists than to English jurisprudence (Bartie 2010). ${ }^{1}$

Since then, LiC has been continuously published due to the efforts and work of many people-Christopher Arup, Paula Baron, Roger Douglas, Pat O’Malley, Margaret Thornton, to mention just a few. Law \& Society world leading scholars from USA, Europe and Asia (India) — such as Richard L. Abel, Upendra Baxi, Stanley Cohen ( $†$ ), Marc Galanter, Doreen McBarnet, Simon Roberts ( $\dagger$ ), and Harry N. Scheiber - served on the Editorial Board and have supported the journal since its inception.

Looking at it from a distance, the coherence of LiC's trajectory is clear. Its first editorial, written by Oliver Mendelsohn, reads:

Law in Context is published as a forum for the inter-disciplinary study of law. For much of the nineteenth and twentieth centuries there was a tendency to reduce the study of law to a narrow technical and doctrinal focus. This coincided with a period when it was only lawyers who were interested in studying law. Now, there is a widespread realisation that law is too important to be left to the lawyers. And the companion view is that legal matters can be more richly understood by placing them in their social context and subjecting them to study from a range of academic disciplines. This first issue of Law in Context exemplifies the inter-disciplinary approach to law. (LiC, Editorial 1983)

Thirty-six year later, all issues of LiC so far continue to show this inter-disciplinary, pluralistic, and especially contextual approach along a variety of disciplines, methodologies and trends. These are in the main Social Sciences, Humanities and Law. Yet it shows something else, more intangible and definitively essential: the will to transcend academic boundaries, i.e. a continuing and firm commitment to not only understand and explain but also participate and eventually remould the deep changes that were occurring after the Cold War and were affecting dramatically the whole society and lives of people in Australia and beyond.
We can track this approach in practically all contributions and, especially, in the collective actions that were generated around the Journal and contributed to shape its differential style and added values-e.g. the creation of legal clinics; the building of feminist discourses; the critical approach to the rule of law; the effort to (re)write legal and institutional history; the defence of democracy and citizenship; the description and criticism of corporate practices and economic organisations; the emergence of Alternative Dispute Resolution (ADR); the close attention to increasing numbers of immigration flows; the study of Asia and individual countries therein; and the support for the cultural, political and judicial fights seeking for the recognition of Aboriginal rights, against the race-based policies that sustained segregation in the immediate colonial past.

In 1988, the Australian Publisher Federation Press commenced publishing Law in Context. Then, in 1995, the former Legal Studies Department at La Trobe University became La Trobe School of Law and Legal Studies (and still later, School of Law). Nevertheless, LiC maintained its original character and orientation. In 2013, the Journal celebrated its thirtieth anniversary-twenty-five years at Federation Press-with a Special Issue on socio-legality, its history, and achievements as an academic discipline (Petersen 2013). ${ }^{2}$

$\mathrm{LiC}$ fostered both innovation and experimentation at a theoretical level. This specific commitment was not exempt from internal dissents. Embracing an open perspective of the law and regulations as socio-political patterns is more challenging than the more classical, textual, normative approach. Thus, LiC's context of discovery reflects the same tensions between the formal (technical) and the substantive (social) approach to law that had characterised legal scholarship in the nineteenth and twentieth centuries - either in the Civil or the Common Law tradition. Perhaps more importantly, it also mirrored the inner disparities and confrontations of invention and

\footnotetext{
${ }^{1}$ This was the case of E. Kingston Braybrooke (1915-1989), who had studied at Columbia Law School in 1949. Columbia was one of the main centres of legal realism, under Karl Llewellyn's leadership. Braybrooke, like Julius Stone (1907-1985) at Harvard, was also influenced by Roscoe Pound's sociological jurisprudence. See Kerruish (1989), Douglas (1989), Kirby (2012), Neil (2013).

${ }^{2}$ This LiC Special Issue, entitled Socio-legality: An Odyssey of Ideas and Context, was edited by Kerry Petersen and introduced by Roger Douglas. It contains essays by some of the leading scholars of the Journal: Christopher Arup, Paula Baron, Susanne Davies, Ian Duncanson, Ian Freckleton, David Neal, and Christopher Tomlins. As acknowledged by Douglas (2013, p. x), "heterogeneity (and, possibly, achievements) came at the cost of conflict."
} 
discovery that occur when epistemic, moral and political assumptions are at stake.

This is not a singular feature. Thinking about government, law and the state in the second half of the 20th century led to discussions and eventually differences among scholars in all Law \& Society disciplines. For instance, after the emergence of legal pluralism in the 1970s and 1980s, and the hatching of globalisation in the 1990s, at the dawn of the new Millennium, Sally Falk Moore summarised the changes in legal anthropology as follows:

What legal domains have anthropologists examined in the fifty years we are considering [1949-1999]? How much have their topics changed? How much do the changes in topic reflect the shifting political background of the period? The big picture is simple enough. What was once a sub-field of anthropology largely concerned with law in non-Western society has evolved to encompass a much larger legal geography. Not only does legal anthropology now study industrial countries, but it has expanded from the local to national and transnational legal matters. Its scope includes international treaties, the legal underpinnings of transnational commerce, the field of human rights, diasporas and migrants, refugees and prisoners, and other situations not easily captured in the earlier community-grounded conception of anthropology, though the rich tradition of local studies continues along a separate and parallel track. (Falk Moore 2001, p. 95)

Thus, anthropologists "are not just talking about what is going on. They also are talking about what could go on [...] They are treating their own critical commentary as a form of social action [emphasis added]" (Falk Moore 2001, p. 111).

This "form of social action" entails a moral and eventually a political judgement, and it conforms a methodology and a notion of law encompassing what Nonet and Selznick (1978) had termed, in accordance with human rights and social challenges, responsive law. Responsive law contrasts with two other notions-repressive and autonomous law - which do not require a similar amount of competence, i.e. knowledge of the social context, the design of better institutions, and the involvement of citizens in power. ${ }^{3}$

The second wave of legal realism-the "new legal realism" - that has blossomed in the first decade of the present century has also embraced this organisational and institutional turn. It can be primarily defined as "an effort to understand the sources of judicial decisions on the basis of testable hypotheses and large data sets" (Miles and Sunstein 2008, p. 831). But, in fact, it goes beyond the judiciary and advanced statistical analysis. It entails an extended notion of context, in which principles, ethics and universal values acquire a new place in the dynamics of evolving institutions." "We do want to judge contexts, which we do by appealing to transcendent values" (Selznick 2003, p. 186). ${ }^{5}$ And, as stated by the scholars who started the discussion, it entails the need to face new comprehensive relationships among the stakeholders themselves:

Our goal is to create translations of social science that will be useful even to legal academics and lawyers who do not wish to perform empirical research themselves, while also encouraging translations of legal issues that will help social scientists gain a more sophisticated understanding of how law is understood "from the inside" by those with legal training. (Erlanger et al. 2005, p. 336)

The pages of Law in Context also reflect this recent regulatory turn, related to new forms of corporate governance, public Health, the relations between law and science, and the relations between quantitative and qualitative methods. $^{6}$

\footnotetext{
${ }^{3}$ According to Nonet and Selznick (1978, p. 78), competence is "the most difficult problem of responsive law: In an environment of pressure the continuing authority of legal purpose and the integrity of the legal order depend on the design of more competent legal institutions."

${ }^{4}$ As put by Nourse and Schaffer (2009, p. 134) "New legal realists refuse to believe that all law and politics should be determined by a single, consequentialist goal, but they also refuse to indulge the fantasy of ethical relativity."

${ }^{5}$ See on the Deweyan Selznick's naturalism, Lieberman (2012).

${ }^{6}$ Hence, to give only one example, Christopher Arup's works elaborated on the multiple possible approaches to better understand innovation, intellectual property, labour, financial and industrial policy, and the implementation and defence of consumer rights in the blurring of private/public global space (Arup 2000). Arup correctly observed that to understand the role of lawyers, law firms and corporations in the process of globalisation, Law and Society scholars had to collect data by means of ethnographic and qualitative methods (e.g. interviews), addressing and sorting out the problem of access to the information. See, for example, Garth and Dézalay (1996, 2002).
} 


\section{CONTEXT AND LAW IN THE DIGITAL AGE}

A new path beckons. It adds a complexity to what $\mathrm{LiC}$ already does yet also provides the opportunity of new fields and discourses. This path is one that the renewed LiC will also now illuminate.

To tread the path for a little distance, we are in a new stage of the same evolution that has led capitalism to its next phase: the digital age. Perhaps we are not able at this time to entirely cope with it, as we cannot anticipate all the consequences that will follow from a technological revolution based on information-processing knowledge, big data analytics, artificial intelligence, and the so-called Internet of Things. These changes are deep, and they have come to stay. Even the scientific method is subject to its impact, due to "the presence of nonlinearity, non-locality and hyper-dimensions which one encounters frequently in multi-scale modelling of complex systems" (Succi and Coveney 2019).

From a foundational point of view, the representation of knowledge is at the heart of the social shape of a digital society that we do not yet know. ${ }^{7}$ Our theoretical assumptions should acknowledge the fact that we behave necessarily not only with limited information but with limited knowledge and tools to handle this information. In an increasingly complex society, law consists of a set of regulatory components that do not constitute separate silos, and there is a plurality of ways to conceive their interrelationship. ${ }^{8}$

From a practical point of view, everything remains open to the building of institutions that could be able to link machine and human interfaces. In a hybrid, semiautomated world, the classical societal micro-macro link goes through the meso-level, in which platforms, apps, blockchains, and digital data are technological components of emergent participatory, civic, democratic, ecosystems (Poblet, Casanovas and Rodríguez-Doncel 2019). However, this intermediate inter-communication level between machines and humans is also the yet-to-befully-regulated domain in which data collection, storage, aggregation, and eventually analysis occur. The problem is who carries out the analyses, how and for what purposes are they performed, and what impacts they may have on individuals and society.

The role of Cambridge Analytica in the British referendum to leave the European Union and in the last presidential elections in the US has opened a Pandora's box. Democracy is certainly at stake (Cadwallader 2018, 2019). But this is just one example among many others in which mass surveillance programs, financial excesses, uncontrolled data exchange between state agencies, manipulation of feelings, prosecution of whistle-blowers, and the convergence between bio-tech and info-tech may led to "digital dictatorships", even under democratic political forms (O’Neil 2016, Harari 2018, Eveleth 2019).

These issues have only been partially addressed so far. In Europe, for example, the promulgation and entry into force (25/05/2019) of the General Data Protection Regulation (DGPR, 2016) enhances a broad range of privacy rights to protect citizens' identities, personal lives and individual autonomy. Likewise, several Reports of the UN Special Rapporteur for Privacy urge the Member States to implement similar safeguards to avoid more data breaches and the evasion and denial of responsibilities by corporations and governments. ${ }^{9}$

However, is this enough? Do we have the right instruments in place to pursue such a noble dream? We are afraid that in a hyperreal world in which reality can be inflated artificially with fake news but true feelings, law and legal measures can be inflated as well. This would entail a loss of meaning. It may well be that the law in

\footnotetext{
7 “One normally thinks that everything that is true is true for a reason. I've found mathematical truths that are true for no reason at all. These mathematical truths are beyond the power of mathematical reasoning because they are accidental and random." (Chaitin 1994) As Chaitin's theorems have shown, information-theoretic computational theory deals (again) with incompleteness. Hence, it is at the limits of mathematics and reason. If some things are true for no reason at all, accidentally, at random, we may expect new black swans in all dimensions of societal levels (Taleb 2007).

${ }^{8}$ Since 2010, the LNAI Workshop Series AI Approaches to the Complexity of Legal Systems shows this plurality of languages and methods for legal and social design. See Pagallo et al. (2018).

${ }^{9}$ See, Reports A/73/45712 and A/HRC/40/6, UN Special Rapporteur on Privacy $(2018,2019)$. There is a direct warning in the second Report: "6. [...] while most Member States unequivocally commit themselves to protecting the right to privacy, many are acting in ways that increasingly put it at risk, by employing new technologies that are incompatible with the right to privacy, such as, in certain modalities, Big Data and health data, infringing upon the dignity of its citizens based on gender or gender identity and expression, as well as by arbitrarily surveying their own citizens."
} 
hyperreal regimes no longer requires legitimacy-the acquiescence of citizens-but obeying in advance. ${ }^{10}$

Shadbolt and Hampson (2018) have pointed out that the regulation of digital societies is an urgent need and, yet, a formidable task. ${ }^{11}$ It cannot be limited just to privacy and security issues - these could be deemed starting points. As underlined by Mathews (2017) what is required now to match civilization requirements is a holistic view bridging systemic and semantic interoperability. All dimensions covered by statutes, regulations, policies, best practices and protocols should be faced through this lens. It is an ethical stance.

Law \& Society has produced cutting-edge research so far in a variety of significant subjects - gender, access to justice, crimes, colonialism, litigation, legal cultures, human rights, the rule of law, dispute resolution, among many others. It might be time to incorporate Computer Science and Artificial Intelligence languages to an epistemic approach for fleshing out such a rich legacy. Thus, the bulk of socio-legal knowledge could be taken further, beyond the conditions in which it was produced, and information technologies could also be incorporated as well into its array of methodologies to shed light on this matter. It would represent a third wave of legal realism.

It is certainly not the only way of handling global-scale changes. Environmentalists may refer and lean on top of the "deep ecology" movement launched by Norwegian philosopher Arne Naess—back in the 1970's. Global climate change has led earth scientists to propose a new division of the geological time as a paradigm to understand the impact of human behaviour on nature-the Anthropocene, which holds also as a political paradigm to ground policies and regulations (Lewis and Maslin 2015). The human body can be approached as well as a new analytical space dealing with bio-ethics, self-reflection and health care-e.g. the "quantified self" of individuals tracking information about their own bodies (Swan 2013, Mittelstadt and Floridi 2016). But, still, all these topics-including those related to Physics and Mathematics-are unthinkable without referring to computer science, robotics and AI running within this interplay between humans and machines that we have termed above the meso-level.

We believe that this mutual approach is felt as a necessity by both Law \& Society and AI \& Law communities. Artificial Intelligence and Law has been working for thirty years now in the modelling of legal norms and legal systems. As L. Thorne McCarty, one of the founding members, recalls in a recent account, it is a common mistake to believe that they were reducing law to rules to be modelled. On the contrary, the flexibility and many ways of creating law-including judicial tests and the "open texture" of its language-were considered as true challenges since the beginning. First wave AI systems were "very good at complex reasoning, but not very good at perception and learning" (McCarty 2019, p. 57). The second and third waves are. Focusing on machine learning, Natural Language Processing (NLP) and Knowledge Representation Technology (semantics) systems are able to better define the problems, to figure out different scenarios in non-identical environments, and to anticipate solutions. We can find many parallels with the evolution of Law and Society and its increasing attention to the transformation of contexts. We recommend interested scholars to read this account in conjunction with Kevin Ashley's contribution about machine learning (in this issue).

\section{ABOUT THIS EDITION: LAW IN CONTEXT FOR THE DIGITAL AGE}

There are many examples of the common ground of Law \& Society and AI \& Law. Knowledge acquisition techniques, the construction of socio-technological systems and socio-cognitive systems, the building of cognitive

\footnotetext{
${ }^{10}$ This is the first lesson from the 20th century drawn by Timothy Snyder to preserve democracy. "Do not obey in advance. Most of the power of the authoritarianism is freely given." (Snyder 2017, p. 16)

11 "Broadly though, a vast range of applications have been engineered on smart devices that seem capable of unlimited marvellous things: translate from one language to another, place a gamer in a virtually real landscape, find the best route through this afternoon's traffic, chat about the weather with granny. There is little or no social policy framework yet around how these applications may be affecting our lives or our brains. There is not enough general understanding of the issues to begin to construct such a framework. Like Prospero's sorcery in The Tempest, these magical transformations have just crept us on the waters, and we have accepted them, without as yet sufficient policy response. We urgently need such a framework." (Shadbolt and Hampson 2018, p. 51) Moreover, coming to the point: "To put it ever more bluntly, the problem is not that machines might wrest control of our lives from the elites. The problem is that most of us might never be able to wrest control of the machines from the people who occupy the command posts [Emphasis added]." (Shadbolt and Hampson 2018, p. 63)
} 
and computational ontologies, the setting of legal and regulatory systems and eco-systems, the structuring and managing of legal data and metadata, all these processes require a closer attention to the work that Law and Society scholars have been carrying out so far. ${ }^{12}$

Related to the $\mathrm{LiC}$ relaunch, we thought that pointing at the concept of legal knowledge as a research object would be a good point of departure to start thinking alike.

We asked several scholars from both fields to freely summarise their own work, their motivations, and personal journeys. We suggested some questions to be answeredHow did you approach law and legal knowledge? Why? What did you learn? What do you think was left in the end?

Some wrote about their research journey; some responded with a thorough description of their recent works; others wrote specific essays of related topics according to their expertise. The result is for the reader to evaluate. We found it interesting, informative, and insightful. We organised it in such a way that some articles are placed in a strategic pivotal position, in the middle of the volume, linking both sides of the equation - socio-legal studies and computer science-through empirical and cultural social sciences and the law. We will describe the contents of the volume from the inside out, and from the centre to the two ends of the rope.

Susanne Davies reflects on the symbolic figure of Atticus Finch, the main character of Harper Lee's 1960 novel To Kill a Mockingbird. This was one of the legal icons of the 20th century for legal and political education, against intolerance, racism and injustice. What happened next so that this figure and its meaning darkened in the 21st century? What about his message now? These questions are properly sociological and do not have a simple answer.

Leaning on their recent books, Capital Failure and Australian Superannuation, Sue Jaffer and Nicholas Morris address the issue of the underlying causes of the Global Financial Crisis (GFC) and the various related scandals that have emerged in UK and Australia. Why did UK financial regulation fail so blatantly to prevent the crisis and its devastating effects? And why is bad behaviour so endemic in the sector? The article also examines how the Australian banking environment has evolved and the inception and development of Fintech and Regtech. The need for new regulatory models from an ethical stance, able to be both more effective and trustworthy, lies at the core of this approach.

Both articles point at the deep social and economic changes that have been occurring in the early 21st century.

The three contributions that open the volume shed light to the legacy, methods and trends of Law and Society studies, and how scholars were (and are) able to raise critical questions with a political and moral value, and with a global scope. Hence, they are also personal, disclosing some of the motivations that trigger research projects, and beyond that, research lives.

On legacy. Lawrence Friedman reflects about two important topics in the present Law and Society movement: the sources of law, on the one hand, and the impact of law, on the other. He suggests the use of legal historical studies as a kind of control group, as studies of modern legal systems show a high degree of convergence. He delves into his own experience to describe the growth and extension of socio-legal studies across different legal cultures in the world, and the benefits that follow from this interconnection.

On conscience. Martin Chanock draws a political and intellectual cartography of his journey through South African history and the construction of a democratic state. He recalls his education and political struggles in South Africa, and how he started asking the right questions and getting the right answers about the functions of law, the implementation of the rule of law, and the institutional creation of customary law in colonial and neo-colonial regimes. This paper contains a sound reflection about truth, politics and the development of legal instrumentsa critical view on "the innocence of legalism" and the incapacity of the state.

On resilience. Richard Abel's work exemplifies citizens' response to the US turn towards democratic authoritarianism. He explores which strategies had been most effective to protect the rule of law against the "war on terror" that followed September 11, threatening American liberties

\footnotetext{
${ }^{12}$ There are many computer scientists working in this interesection-Pablo Noriega, Tom van Engers, Jeremy Pitt, Frank and Virginia Dignum, among many others. For a general overview on normative-multiagent systems, see Andriguetto et al. (2013); for the state of the art in law and the semantic web, Casanovas et al. (2016).
} 
under Bush and Obama administrations. He summarises the findings of his two recent books-Law's Wars and Law's Trials - concluding that the rule of law "whose raison d'être is to immunize law from political distortion, itself depends on politics."

Finally, this volume collects several papers that refer to the uses, developments and methods of technology in the legal domain. These papers bring us back to reality that impacts on our personal and professional lives.

Zhiqiong June Wang's contribution focuses on legal education and technology. She brings into consideration three main issues: the adoption and adaptation of technologies to teaching and learning, the study and research of their impacts on society to formulate legal responses, and the preparation of future lawyers. She concludes by stressing the human side and its critical role in the evolution of legal education: law demands a "human touch", and that calls for human values and empathy.

From a computer science perspective, John Zeleznikow offers an accurate and deep insight of what such a "human touch" means. His work has been centred on empowering citizens through the development of Online Dispute Resolution (ODR) systems providing tools for self-represented litigants. His contribution to the present volume recalls how he became increasingly aware of the importance of modelling legal realism. From the early use of machine learning to more complex solutions, he realised that law was more than a mere application of rules: "Law is used as a social device to reflect society's changing attitudes."

We situated Kevin Ashley's article at the end of this volume, last but not least. It consists of an illuminating account of the evolution of Machine Learning (ML) techniques across the $\mathrm{AI}$ and Law field. Understanding the rationale of judicial sentencing and being able to predict the outcomes have always been one of the aims of legal realism. So has it been for computer scientists as well. Focusing on recent developments in legal text analytics and the techniques to extract meanings from legal decisions, contracts and statutes, this article explains in detail how bottom-up approaches enrich and complement top-down ones. What is actually possible, why, and what is next.

\section{LAW IN CONTEXT IN OPEN ACCESS}

From Issue 36 (1) onwards Law in Context (LiC) will be published in an Open Access format. It complies with the sixteen Principles of Transparency and Best Practice in Scholarly Publishing published by the Committee on Publication Ethics, the Directory of Open Access Journals, the Open Access Scholarly Publishers Association, and the World Association of Medical Editors. ${ }^{13}$ It also follows the ten core practices of the Committee on Publication Ethics, and the policies of the Australasian Open Access Strategy Group chart. ${ }^{14}$

According to its tradition, Law in Context is keen to publish original and pathbreaking contributions in the fields of legal studies, legal scholarship and jurisprudence. We will of course be happy to host Technology/AI \& Law approaches to these fields, so that we can see where this new path may lead us.

\section{REFERENCES}

1. Andrighetto, G., Governatori, G., Noriega, P. and van der Torre, L.W. 2013. Normative multi-agent systems (Vol.4). Schloss Dagstuhl-Leibniz-Zentrum für Informatik. http:// drops.dagstuhl.de/opus/volltexte/dfu-complete/dfu-vol4complete.pdf Accessed 30/8/2019.

2. Arup, C. 2000. The New World Trade Organization Agreements. Globalizing Law Through Services and Intellectual Property. Cambridge: Cambridge University Press.

3. Bartie, S. 2010. "A full day's work: a study of Australia's first legal scholarly community." U. Queensland LJ, 29 (1): 67-99.

4. Berghel, H. 2017. Equifax and the latest round of identity theft roulette. Computer, 50 (12): 72-76.

5. Cadwallader, C. 2019. Ted Talk, "Facebook's role in Brexit, and the threat to democracy", 19 April. https://www.ted. com/talks/carole_cadwalladr_facebook_s_role_in_brexit_ and_the_threat_to_democracy?language $=$ en Accessed $30 / 8 / 2019$.

6. Cadwalladr, C. (2018). Exposing Cambridge Analytica: 'It's been exhausting, exhilarating, and slightly terrifying'. The Guardian, 28 September. https://www.theguardian.com/ membership/2018/sep/29/cambridge-analytica-cadwalladrobserver-facebook-zuckerberg-wylie Accessed 30/8/2019.

\footnotetext{
${ }^{13}$ DOAJ Principles. Last version: 15 January 2018.

${ }^{14}$ ARC \& NHMRC policy compliance by an institution: https://aoasg.files.wordpress.com/2013/05/arc_nhmrc_institution_compliance_flowchart.pdf
} 
7. Casanovas, P., Palmirani, M., Peroni, S., van Engers, T. and Vitali, F. 2016. "Semantic web for the legal domain: the next step”. Semantic Web Journal 7 (3): 213-227.

8. Chaitin, G.J. 1994. The limits of mathematics. Preprint. https://arxiv.org/pdf/chao-dyn/9407003.pdf Accessed 30/8/2019.

9. Dezalay, Y. and Garth, B.G., 2002. The internationalization of palace wars. Lawyer, Economists, and the Contest to Transform Latin American States. Chicago: University of Chicago Press.

10. Dézalay, Y. and Garth, B.G.1996. Dealing in virtue: International commercial arbitration and the construction of a transnational legal order. Chicago: University of Chicago Press.

11. Douglas, R. 2013. "Foreword". Socio-legality: An Odyssey of Ideas and Context. Law in Context 29 (2): ix-xii.

12. Dryzek J.S. and Niemeyer N. "Deliberative Turns" (2009). In J. Dryzek (ed.) Foundations and Frontiers of Deliberative Governance. Oxford Scholarship Online, pp. 3-17.

13. Erlanger, H., Garth, B., Larson, J., Mertz, E., Nourse, V., Wilkins, D. 2005. "Is it Time for a New Legal Realism?" Wisconsin Law Review, (2): 335-363.

14. Eveleth, R. 2019. "Ideas. When Futurism let to Fascism —and why it could happen again”. 18 April 2019. Wired, https://www.wired.com/story/italy-futurist-movementtechno-utopians/ Accessed 30/8/2019.

15. Falk Moore, S. 2001. "Certainties undone: Fifty turbulent years of legal anthropology, 1949-1999." Journal of the Royal Anthropological Institute, 7 (1): 95-116.

16. GDPR, 2016. Regulation (EU) 2016/679 of the European Parliament and of the Council of 27 April 2016 on the protection of natural persons with regard to the processing of personal data and on the free movement of such data, and repealing Directive 95/46/EC (General Data Protection Regulation). https://eur-lex.europa.eu/eli/reg/2016/679/oj accessed 25/8/2019 Accessed 30/8/2019.

17. Harari, Y.N. (2018). 21 Lessons for the 21st Century. London: Jonathan Cape. https://www.springer.com/gp/ book/9783030133627

18. Kerruish, V. 1989. "In Memory of Ernest Kingston Braybrooke." UW Austl. L. Rev. 19 (2): 198-199.

19. Kirby, M. 2012. "A.R. Blackshield and Realism in Australian Constitutional Law." Macquarie LJ 11: 7-21.

20. Lewis, S.L., and Maslin, M.A 2015. "Defining the anthropocene." Nature 519 (7542): 171-179.

21. LiC (1983). Editorial. Law in Context. A Socio-legal Journal 1: iii.
22. Lieberman, D. 2012. "Why Law: Philip Selznick and the Study of Normative Systems." Issues Legal Scholarship, 10 (1): 33-42.

23. Mathews, R. 2017. "Interrogating 'Privacy' in a World Brimming with High Political Entanglements, Surveillance, Interdependence \& Interconnections". In R. Mathews (ed.) Special Issue: Privacy and Security of Medical Information. Health and Technology (7): 265-322.

24. McCarty, L.T. 2019. "Finding the Right Balance in Artificial Intelligence and Law". In Bartfield, W. and Pagallo, U. (eds.) Research Handbook on the Law of Artificial Intelligence. Cheltenham, UK, and Northhampton, MA, USA: Edward Elgar Publishing, pp. 55-87.

25. Miles, T.J. and Sunstein, C. R. 2008. "The New Legal Realism." The University of Chicago Law Review 75 (2): 831-851.

26. Mittelstadt, B.D. and Floridi, L. (eds.). 2016. The ethics of biomedical big data. Law Governance and Technology Series, vol. 29. Dartmouth: Springer.

27. Neal, D. 2013. "Law and power-livin'in the'70s." Law in Context: A Socio-Legal Journal, 29: 99-136.

28. Nonet, P. and Selznick, P. 1978. Law and Society in Transition. Toward Responsive Law. New York: Octagon Books.

29. Nourse, V. and Shaffer, G. 2009. "Varieties of New Legal Realism: Can a New World Order Prompt a New Legal Theory." Cornell Law Review 95 (1): 61-137.

30. O'Neil, C. 2016. Weapons of math destruction: how big data increases inequality and threatens democracy (First edit). New York: Crown.

31. Pagallo, U., Palirani, M., Casanovas, P., Sartor, G., Villata, S. (eds.) 2018. AI Approaches to the Complexity of Legal Systems. AICOL International Workshops 2015-2017. LNAI 10791, Cham: Springer International Publishing.

32. Petersen, K. (ed.) (2013). Socio-legality: An Odyssey of Ideas and Context. Special Issue. Law in Context 29 (2): 1-163.

33. Poblet, M., Casanovas, P., and Rodríguez-Doncel, V. (2019). Linked Democracy. Foundations, methodologies, applications. Cham: Springer Nature.

34. Selznick, P. 2003. "'Law in Context' Revisited." Journal of Law and Society, 30 (2): 177-186.

35. Shadbolt, N. and Hampson, R. (2018). The Digital Ape: How to Live (in Peace) with Smart Machines. London, Melbourne: Pan Macmillan.

36. Snyder, T. (2017). On Tyranny. Twenty Lessons from the Twentieth Century. New York: Tim Duggan Books.

37. Succi, S., and Coveney, P.V. 2019. "Big data: the end of the scientific method?" Philosophical Transactions of the Royal 
Society A 377, 2142: 20180145. http://dx.doi.org/10.1098/ rsta.2018.0145

38. Swan, M., 2013. "The quantified self: Fundamental Disruption in Big Data Science and Biological Discovery." Big data, 1 (2): 85-99.

39. Taleb, N. N. 2007. The Black Swan: The Impact of the Highly Improbable. New York: Random House.

40. The Guardian, 2019. "Australian National University hit by huge data breach", 4 June. https://www.anu.edu.au/news/ all-news/message-from-the-vice-chancellor
41. UN Special Rapporteur on Privacy. 2018. A/73/45712. Report of the Special Rapporteur on the Right to Privacy. 17 October.

42. UN Special Rapporteur on Privacy. 2019. A/HRC/40/63. Report of the Special Rapporteur on the Right to Privacy. 27 February. 